|| ISSN(online): 2589-8698 || ISSN(print): 2589-868X ||

International Journal of Medical and Biomedical Studies

Available Online at www.ijmbs.info

NLM (National Library of Medicine ID: 101738825)

Index Copernicus Value 2019: 79.34

Original Research Article

Volume 5, Issue 10; October: 2021; Page No. 165-169

\title{
STUDY OF LYMPH NODE CYTOLOGY IN HIV INFECTED PATIENTS
}

\section{Dr. Abhijeet Ramesh Dhawale}

MD, Pathology, Assistant Professor, Vedantaa Institute of Medical Sciences, Saswand, Dahanu (Palghar) Maharashtra

\author{
Article Info: Received 07 October 2021; Accepted 28 October 2021 \\ DOI: https://doi.org/10.32553/ijmbs.v5i10.2284 \\ Corresponding author: Dr. Abhijeet Ramesh Dhawale \\ Conflict of interest: No conflict of interest.
}

\begin{abstract}
Background and Aim: Human immunodeficiency virus (HIV) infection has become a global pandemic. Persistent generalized lymphadenopathy (PGL) is very common manifestation of HIV infection. Moreover, different opportunistic infections such as tuberculosis (TB) and malignancies may present with lymphadenopathy. This study was performed to evaluate the role of FNAC as a cytological investigative tool in the diagnosis of various lesions in HIV lymphadenopathy.

Material and Methods: This study was carried out in Tertiary care Institute of India, over a period of one year. Total 50 cases of HIV lymphadenopathy patients were participated in the study after having signed the Informed Consent Form. Diagnosis of HIV was done by enzyme linked immunosorbant assay (ELISA) test, followed by the CD4 counts by BD FACS Count system in HIV positive patients. FNAC procedure was performed as an OPD procedure in cytology OPD of pathology department.

Results: Most common site of HIV lymphadenopathy is cervical lymph node $40(80 \%)$, followed by supraclavicular $6(12 \%)$ followed by axillary lymph node $4(8 \%)$. The most common lesion found was mycobacterial infection $22(44 \%)$, followed by reactive lymphadenitis $15(30 \%)$. Non-specific chronic granulomatous lymphadenitis in $10(22 \%)$ and $3(6 \%)$ cases of acute suppurative lymphadenitis. CD4 count more than 500 cells $/ \mu \mathrm{L}$ was seen in $9(18 \%)$ cases of reactive lymphadenitis and $4(8 \%)$ cases of chronic granulomatous lymphadenitis. Patients with tubercular infection had CD4 count between 200- 499 cells/ $\mu \mathrm{L}$ in $12(24 \%)$ cases and less than 200 in $10(20 \%)$ cases.

Conclusion: FNAC is relatively inexpensive and valuable tool for identification of opportunistic infections, neoplastic lesions and non-neoplastic lesions. It may spare patients lymph node excision and enable immediate treatment of specific infection. This procedure is readily repeatable and can be used for follow up during and after treatment.

Keywords: Human immunodeficiency virus, lymphadenopathy, Non-specific chronic granulomatous lymphadenitis, tuberculosis
\end{abstract}

\section{Introduction}

Acquired immunodeficiency syndrome (AIDS) is known to be caused by a lymphotropic retro-virus ie.Human immunodeficiency virus (HIV), first described by French investigators and later by investigators in United States. AIDS was first recognized in 1981.1 Acquired Immuno Deficiency Syndrome (AIDS) related lymphadenopathy has definite patterns like florid reactive hyperplasia, folliculolysis, explosive follicular hyperplasia, advanced lymphocytic depletion with or without abnormal regressively transformed germinal centers and vascular transformation. HIV disease can be divided on the basis of immunodeficiency into an early stage [cluster of differentiation $(\mathrm{CD}) 4>500 / \mu \mathrm{L}]$, an intermediate stage $(\mathrm{CD} 4=200-500 / \mu \mathrm{L})$, and an advanced stage $(\mathrm{CD} 4<$ 200/ $\mu \mathrm{L}) .2,3$ Most AIDS-defining opportunistic infections and malignancies occur in the advanced stage of the disease. 4,5

HIV enters the body through mucosal tissues and blood and first infects $\mathrm{T}$ cells and dentritic cells and macrophages. The infection becomes established in lymphoid tissues, active viral replication is associated with more infection of cells and progression to AIDS. AIDS is a fatal illness that breaks down the body's immunity and leaves the victim vulnerable to life threatening opportunistic infections, neurological disorders or unusual malignancy.6 Lymphoid tissue is a favorite target for the initial viral infection, subsequent opportunist infections and Human Immunodeficiency Virus (HIV) associate neoplasm.7

Persistent generalized lymphadenopathy (PGL) is a very common manifestation of HIV infection. Moreover, different opportunistic infections such as tuberculosis (TB), toxoplasmosis, disseminated fungal infections, atypical mycobacterial infections, Cytomegalovirus infection, and malignancy such as non-Hodgkin lymphoma (NHL) may present with lymphadenopathy.5 TB occurs when the CD4+ count has just started to decline and is $200-500$ cells $/ \mu \mathrm{L} .6,7$ Mycobacterium avium complex (MAC) infection is most common with CD4+ count $\leq 50$ cells $/ \mu \mathrm{L} .8$

The role of fine needle aspiration cytology (FNAC) in evaluation of lymphadenopathies is well known. FNAC can serve as alternative method and may be practiced for the diagnosis of opportunist infection in HIV/ AIDS, eg: - 
tuberculosis, histoplasmosis, toxoplasmosis and malignant condition such as Kaposi's sarcoma and lymphoma. Fineneedle aspiration cytology (FNAC) offers a simple and effective modality for obtaining a representative sample of the material from lymph nodes, permitting cytological evaluation and other investigations. This study was performed to evaluate the role of FNAC as a cytological investigative tool in the diagnosis of various lesions in HIV lymphadenopathy.

\section{Material and Methods}

This study was carried out in Tertiary care Institute of India, over a period of one year. Total 50 cases of HIV lymphadenopathy patients were participated in the study after having signed the Informed Consent Form. Diagnosis of HIV was done by enzyme linked immunosorbant assay (ELISA) test, followed by the CD4 counts by BD FACSCount system in HIV positive patients. FNAC procedure was performed as an OPD procedure in cytology OPD of pathology department. The swelling was localized by careful palpation and site was cleaned with spirit and fixed in favorable position with one hand, and 22 or 23 gauge needle was attached to $10 \mathrm{cc}$ syringe fitted on to comeco syringe pistol and FNAC was done. Smears were immediately fixed in $95 \%$ ethyl alcohol for PAP staining. Air dried smears were kept for MGG, AFB and special stain for fungi PAS and Methinamine Silver.

\section{Results}

Total 50 HIV positive patients were included in this study, out of which 33 are males and 17 are females. This shows that there is predominance of males over the females. Also it is evident that majority of male patients are between 30 to 40 years of age, whereas majority of females are in between 20 to 30 years of age. Most common site of HIV lymphadenopathy is cervical lymph node $40(80 \%)$, followed by supraclavicular 6(12\%) followed by axillary lymph node $4(8 \%)$. The most common lesion found was mycobacterial infection 22(44\%), followed by reactive lymphadenitis $15(30 \%)$. Non-specific chronic granulomatous lymphadenitis in $10(22 \%)$ and $3(6 \%)$ cases of acute suppurative lymphadenitis. The diagnosis of tuberculous lymphadenitis was considered only when smear for Acid Fast Bacilli (AFB) were positive.

Tubercular infection was the most common opportunist infection. These cases were grouped into four categories in which predominant pattern were smears showing caseous necrosis with epithelioid cells in $9(40.9 \%)$ cases. Within this group we found giant cell formation in two cases. Followed by smears showing only caseous necrosis in 8 (36.6\%) cases. $3(13.6 \%)$ cases showed only epitheloid cells and $2(9.09 \%)$ cases shows suppurative changes.

CD4 count more than 500 cells/ $\mu \mathrm{L}$ was seen in $9(18 \%)$ cases of reactive lymphadenitis and $4(8 \%)$ cases of chronic granulomatous lymphadenitis. Patients with tubercular infection had CD4 count between 200- 499 cells/ $\mu \mathrm{L}$ in 12 $(24 \%)$ cases and less than 200 in $10(20 \%)$ cases. In chronic granulomatous lymphadenitis $4(8 \%)$ cases had CD4 count more than 500 cells/ $\mu \mathrm{L}, 3(6 \%)$ cases had CD4 count in between 200 to 499 cells/ $\mu \mathrm{L}$ and $3(6 \%)$ cases had CD4 count less than 200 cells/ $\mu \mathrm{L}$. In acute suppurative lymphadenitis $2(4 \%)$ cases had CD4 count in between 200 to 499 cells/ $\mu \mathrm{L}$, and $1(2 \%)$ case had CD4 count less than 200 cells $/ \mu \mathrm{L}$.

Table 1: Distribution of Age and Sex in HIV patients in the study

\begin{tabular}{|l|l|l|}
\hline Years & Males & Female \\
\hline $\mathbf{1 - 1 0}$ & 1 & 1 \\
\hline $\mathbf{1 1 - 1 9}$ & 1 & 1 \\
\hline $\mathbf{2 0 - 2 9}$ & 9 & 9 \\
\hline $\mathbf{3 0 - 3 9}$ & 18 & 6 \\
\hline $\mathbf{4 0 - 4 9}$ & 4 & 0 \\
\hline $\mathbf{5 0 - 5 9}$ & 0 & 1 \\
\hline Total & 33 & 17 \\
\hline
\end{tabular}

Table 2: Distribution of Cases According to Cytological Diagnosis in HIV Positive Patients in the Study

\begin{tabular}{|l|l|l|}
\hline Diagnosis & Number of patients & Percentage (\%) \\
\hline Mycobacterial Infection & 22 & 44 \\
\hline Reactive lymphadenitis & 15 & 30 \\
\hline Nonspecific chronic granulomatous lymphadenitis & 10 & 20 \\
\hline Acute suppurative lymphadenitis & 3 & 6 \\
\hline Total & 50 & 100 \\
\hline
\end{tabular}


Table 3: Comparison of CD4 Cell Count with Different Cytological Diagnosis

\begin{tabular}{|l|l|l|l|l|}
\hline CD4 count (cells/ $\boldsymbol{\mu L})$ & Tubercular & Reactive & Chronic grannulomatous & Acute suppurative \\
\hline$>\mathbf{5 0 0}$ & 0 & 9 & 4 & 0 \\
\hline $\mathbf{2 0 0 - 4 9 9}$ & 12 & 6 & 3 & 2 \\
\hline$<\mathbf{2 0 0}$ & 10 & 0 & 3 & 1 \\
\hline
\end{tabular}

\section{Discussion}

Lymph nodes, which form the bulk of lymphoid tissue, are the major anatomic sites for establishing and propagation of HIV infection. More over Iymphnodes are the filters of opportunistic pathogens. Some patients suffer progressive generalised lymphadenopathy (PGL) relatively early in the disease while others may experience varying degrees of transient lymphadenopathy. Lymphnode involvement is a common denominator of virtually all patients with HIV infection. Asymptomatic stage may extend up to 10 years or longer as reported in western literature. Symptoms are associated with onset of opportunistic infections.10 The prolonged asymptomatic phase does not appear to be associated with Indian patients, India is in the epicentre of HIV pandemic. Till such time a definitive therapeutic modality for AIDS is established, the strategy of management of these cases is going to be early detection and prompt treatment of opportunistic infections. Six monthly review and surveillance is essential to monitor the cases. $\mathrm{d}$ surveillance is essential to monitor the cases, The opportunistic infections depend on the microbiological milieu of the individual and the community. The pattern of the disease is different in Indian scenario, compared to western literature. 11,12

HIV being a lymphotropic virus, lymphadenopathy is a very common manifestation of HIV infection.13-15Apart from other causes such as TB, opportunistic infections and NHL, HIV itself can cause reactive follicular hyperplasia, which manifests as PGL.[14-16] FNAC being a minimally invasive, cost-effective, and rapid procedure, it was used as a diagnostic procedure to determine the cause of lymphadenopathy in these patients.13-15

In present study FNAC was performed on 50 HIV positive patients, who presented with lymphadenopathy. Out of the 50 patients, 33 were males and 17 were females with male to female ratio of $1.7: 1$. Out of the 50 patients 2 patients were between $1-10$ years. 2 were between $10-19$ years. 18 were between 20-29 years. 24 patients were in between 30 -39 years. Majority of males were affected in 30-49 years of age and majority of females affected in 20-29 years of age. Findings of our study correlate well with the Shenoy et al16, Vanisiri et al17 and Rajasekaran et al18

Most common site of HIV lymphadenopathy is cervical lymph node $40(80 \%)$, followed by supraclavicular $6(12 \%)$ followed by axillary lymph node 4(8\%). Finding of our study correlate well with the studies of Bates et all9, Jayaram et al20. and Kumarguru et al.21
Tubercular lymphadenitis was the most common finding in the present study, Reactive lymphadenitis was second most common diagnosis in present study. Reactive lymphadenitis and Mycobacteria infection are the 2 most findings in the almost all study. In study conducted by Bates et al19, Reid et al22 and Satyanarayna et al 23 most common cytology finding is reactive lymphadenitis while in study conducted by Shenoy et al16, Vanisri et al17 and in present study most common finding is tuberculosis.

AFB positivity was taken as criteria for diagnosis of tuberculosis. Bezabih et al., Handa et al., and Gupta et al. have reported ZN positivity of $37.4-59.4 \%$ in aspirates from tubercular lymphadenitis. 24,25

This observation indicates that in Indian population tuberculosis is more common in HIV lymphadenopathy than in Western Countries. Reactive lymphadenitis was second most common diagnosis in present study; it was identified by proliferation of polymorphic lymphocytic population with centroblasts, centrocytes immunoblasts, plasma cells, small lymphocytes and pale histiocytes in variable proportions with no any other specific findings. Neoplastic lesions were not found in our study .In other studies Bates at el19 noted 4\%, Reid et al $229 \%$ and Shenoy et al16 $8.9 \%$ cases of lymphoma, while Satyanarayana et al23 noted $2.6 \%$ and Vanisri et al17 $2.7 \%$ cases of lymphoma.

In all the patients CD4 count was compared with cytological pattern. Out of total 15 reactive lymphadenitis cases CD4 count was $>500 / \mu \mathrm{L}$ with mean of 645.5 cells $/ \mu$ $\mathrm{L}$ in 9 of cases, and in between 200-499 with the mean of 301.2 cells $/ \mathrm{u} \mathrm{L}$ in 6 of cases. There was significant association between AFB positivity and low CD4+count ( $\mathrm{P}$ $=0.05)$, which was in accordance with the study of Gautam et al. and Jones et al.2,3

FNAC is an excellent tool for evaluation of lymphadenopathy in HIV positive patients. FNAC should be performed even when the lymph nodes are less than I em size. Axillary lymph nodes pose problem for the performer of the procedure, but blind FNAC without fixing the node should be attempted as this also provides useful material.

FNAC is useful for detection of mycoses and neoplasia in lymph nodes of HIV infected patients. All suspected neoplasia should be biopsied to avoid false positivity. Infection by Rhodo torula in HIV positive patient is reported for the first time. Association of Kimura's disease and HIV is reported for the first time. CD4, CD8 counts 
done along with needle aspiration will give better clinicopathological correlation, as immune status vis-a-vis the opportunistic infections in Indian setting can be assessed. Immuno-fluroscence for viral antigens and Toxoplasma, if done, could pick up these infectious agents better on the smears.

\section{Conclusion}

FNAC is relatively inexpensive and valuable tool for identification of opportunistic infections, neoplastic lesions and non-neoplastic lesions. It may spare patients lymph node excision and enable immediate treatment of specific infection. This procedure is readily repeatable and can be used for follow up during and after treatment. Correlation of lesions with CD4 T lymphocyte counts provides information about the immune status and stage of the disease. Thus FNAC is a primary, easy and effective diagnostic modality for HIV lymphadenopathy patients. It helps in identifying majority of the reactive and neoplastic lesions and opportunistic infections and guide for the subsequent management of the patient. FNAC findings in the HIV lymphadenopathy are noticeably different in India in comparison to the Western Countries.

\section{References}

1. Vanisri HR, Nandini NM, Sunila R, Fine-needle aspiration cytology findings in human immunodeficiency virus lymphadenopathy. Indian Journal of Patho. micro. 2008;51(4):481-4.

2. Gautam H, Bhalla P, Saini S, Dewan R. Correlation between baseline CD4 + T-Lymphocyte count and plasma viral load in AIDS patients and their early clinical and immunological response to HAART: A preliminary study. Indian $\mathrm{J}$ Med Microbiol 2008;26:256-8.

3. Jones BE, Young SM, Antoniskis D, Davidson PT, Kramer F, Barnes PF. Relationship of the manisfestations of tuberculosis to CD4 cell counts in patients with human immunodefi ciency virus infection. Am Rev Respir Dis 1994;148:1292-7.

4. Sengupta D, Rewari BB, Mishra SN, Joshi PL, Prasada Rao JV. Spectrum of opportunistic infections in AIDS: Trends from India. J Indian Acad Clin Med 2000;4:99103.

5. Arora VK, Kumar SV. Pattern of opportunistic pulmonary infections in HIV sero-positive subjects: Observations from Pondicherry, India. Indian J Chest Dis Allied Sci 1999;41:135-44.

6. Kumar V, Abbas AK, Fausto N, Aster JC, Disease of immune system, Robbins and Cotran Pathologic basis of Disease, 8th South Asia edn, Elsevier publication,2010, 235-249.

7. Satyanarayana S, Kalghatgi AT, Muralidhar A, Prasad RS, Jawed KZ, Trehan A. Fine needle aspiration cytology of lymph nodes in HIV infected patients. Med J Armed Forces India 2002;58:33-7.
8. Nightingale SD, Byrd LT, Southern PM, Jockusch JD, Cal SX, Wynne BA. Incidence of Mycobacterium avium-intracellulare complex bacteremia in human immunodefi ciency virus-positive patients. J Infect Dis 1992;165:1082-5.

9. Cooper MD. Alexander R. Lawton m. Primary immune deficiency diseases. In: Isselbacher $\mathrm{KJ}$, Braunwald E, Wilson JO, Manin IB, Fauci AS. Kasper DL, editors. 13thed. McGraw Hill inc. 1994;1559-618.

10. Lapuerta P. Manin SE, Ellison E. Fine needle aspiration of peripheral lymph nodes in patients with tuberculosis and mv. Am 1 Clin Patholl997;107(3):317-20.

11. Stringle SM. Manin SE, Levine AM, Rarick MU. The use of fine needle aspiration cytology in the management of human immunodeficiency virus related non-Hodgkin's lymphoma and Hodgkin's disease. I Acquir Immune Defic Syndr I993;6(12): 1329-34.

12. Alfonso F. Gallo L, Winkler B. Suhrland MI. Fine needle aspiration cytology of peripheral lymph node cryptococcosis, A report ofthree cases. Acta Cytol 1994;38(3):459-62.

13. Saikia UN, Dey P, Jindal B, Saikia B. Fine needle aspiration cytology in lymphadenopathy of HIVpositive cases. Acta Cytol 2001;45:589-92.

14. Jayaram G, Chew MT. Fine needle aspiration cytology of lymph nodes in HIV-infected individuals. Acta Cytol 2000;44:960-6.

15. Isaakidis $\mathrm{P}$, Das M, Kumar AM, Peskett $C$, Khetarpal $\mathrm{M}$, Bamne A, et al. Alarming levels of drug-resistant tuberculosis in hiv-infected patients in metropolitan Mumbai, India. PLoS One 2014;9:e11046.

16. Shenoy R, Kapadi SN, Pai KP, Kini H, Mallya S, Khadilkar UN, et al. Fine needle aspiration diagnosis in HIV related lymphadenopathy in Mangalore, India. Acta Cytol 2002;46:35-9.

17. Vanisri HR, Nandini NM, Sunila R, Fine-needle aspiration cytology findings in human immunodeficiency virus lymphadenopathy. Indian Journal of Patho. micro. 2008;51(4):481-4.

18. Rajasekaran S, Gunasekaran M, Bhanumati V. Tuberculous cervical lymphadenitis in HIV positive and negative patients. Ind J Tub 2001; 48: 201-04.

19. Bates ME, Tanner A, Suvarna SK, Glazer G, Coleman DV. Use of fine needle aspiration cytology for investigating lymphadenopathy in HIV positive patients. J Clin Pathol 1993;46:564-6.

20. Jayaram G, Chew MT. Fine needle aspiration cytology of lymph nodes in HIV-infected individuals. Acta Cytol 2000;44:960-6.

21. Kumarguru BN, Kulkarni MH, Kamaken NS. FNAC of peripheral lymph nodes in HIV positive patients. Sci Med 2009:4-12.

22. Reid AJ, Miller RF, Kocjan GL. Diagnostic utility of fine needle aspiration (FNA) Cytology in HIV- 
infected patients with lymphadenopathy. Cytopathology 1998;9:230-9.

23. Satyanarayana S, Kalghatgi AT, Muralidhar A, Prasad RS, Jawed KZ, Trehan A. Fine needle aspiration cytology of lymph nodes in HIV infected patients. Med J Armed Forces India 2002;58:33-7.
24. Gupta AK, Nayar M, Chandra M. Critical appraisal of fi ne needle aspiration cytology in tuberculous lymphadenitis. Acta Cytol 1992;36:391-4.

25. Bezabih M, Marium DW, Selassie SG. Fine needle aspiration cytology of suspected tuberculous lymphadenitis. Cytopathology 2002;13:284-90. 